\title{
Applying Political Theory to International Law
}

Justifying International Acts. By Lea Brilmayer.* Ithaca: Cornell University Press, 1989. Pp. x, 164. $\$ 19.95$.

\section{Stanley Hoffmann $\dagger$}

Professor Brilmayer's book examines the justification of a government's activities beyond the borders of the state. She notes, correctly, that classical "horizontal" theories of international law that focus on the relations among states cannot cope adequately with what she calls "diagonal relationships," by which she means "state-individual relations with international overtones," such as the relation of a state to a nonresident guest worker, or to human beings whose rights are violated in their home country and whom the foreign state tries to protect. ${ }^{1}$ She shows that neither "state-moralists"-for whom international law ethics are a matter of states' rights-nor realists-who doubt the relevance of ethical considerations in foreign policy and the effectiveness of international law-have much to say about such links. Further, she argues that cosmopolitans-for whom borders have no moral significance-practice their own brand of horizontalism, as they see the world as a net of inter-personal relations across borders. ${ }^{2}$ She also deplores the failure of political theory to explore issues of transnational relations, and its tendency to focus almost exclusively on "the question of domestic political legitimacy," that is, a citizen's obligation to obey his or her own government, rather than on non-citizens' rights and duties. ${ }^{3}$

Her attempt to remedy these failings is "vertical analysis." Her thesis is simple (and repeated many times): "a state's actions outside its territory . . . must be evaluated in terms of the political justification that grants that state the right to operate domestically." "Thus, "all transjurisdictional relations . . . should be analyzed in terms of domestic political theory."

\footnotetext{
* Nathan Baker Professor of Law, Yale Law School.

+ Douglas Dillon Professor of the Civilization of France, Harvard University.

1. L. Brilmayer, Justifying International ACTs 84 (1989) [hereinafter cited by page number only].

2. Pp. 29-34.

3. P. 52 .

4. P. 2 .

5. P. 3.
} 
She explains that she is engaged, not in a "first-order enterprise" that adopts the premises of a given political theory and draws "from them conclusions about the legitimate scope of state coercion in international relations," but in a "second-order inquiry" which merely draws out the implications of the "vertical thesis's consistency requirement" (the requirement that the same "constituting political theory" grant a state authority to act at home and abroad). ${ }^{8}$

Unfortunately, despite the clear and elegant writing and subtle analytic intelligence displayed throughout the volume, it is not at all clear that the vertical thesis gets us any farther than the domestic and international theories whose shortcomings Brilmayer so accurately picked out. Indeed, the volume struck this reviewer as a bundle of contradictions. Why, in the first place, can't the state's "constituting political theory" itself sharply distinguish between the principles of legitimacy at home and the principles to be applied in the thoroughly different international milieu? (The United States Supreme Court has granted the President far greater powers abroad than at home). Is not the absence of a sovereign above the states relevant to the distinction between "diagonal" relationships and the other set of vertical ones, state-citizen relations? Moreover, Brilmayer devotes a whole chapter ${ }^{2}$ (in my opinion, her best) to what she calls the boundary assumptions of domestic political theory. She asserts that every theory of domestic legitimacy, such as explicit or tacit consent or acceptance of benefits, turns "on implicit assumptions about the boundaries of sovereignty,"8 that is, assumptions about territoriality: "all theories of political obligation depend on the existing distribution" of territory. ${ }^{9}$ If this is the case, as she convincingly argues, then why should the same justification be required for acts within the boundaries and for acts without? Is there not a strange coincidence or convergence in oversimplification between this requirement of consistency and the "horizontal" world view of cosmopolitan theorists?

Brilmayer would deny it, since she insists that her "metatheoretical" endeavor allows each state to have its own theory of legitimacy, and merely demands "theoretical consistency between domestic justification and international coercion."10 But this is an untenable position. Indeed, Brilmayer dismisses one objection to vertical analysis, "that it grants too much power to a state that was founded on an unprincipled domestic political theory"11 (for instance a theory that justifies aggression, or interference in external affairs), by arguing that the objection fails to "distinguish

\footnotetext{
6. Pp. 22-23.

7. Pp. 52-78.

8. P. 65.

9. P. 75 .

10. P. 24.

11. P. 47 .
} 
between a valid political theory and one that is merely held sincerely."12 But in order to decide which is valid and which is not, or to "resolve conflicts between states with fundamentally different political systems,"1s one needs a metatheory that will supply "the criteria for evaluating political actions," 14 and thereby determine which "constituting political theories"15 are philosophically and existentially acceptable and which are not. If, as Brilmayer does in this volume, one refuses to do so, then it is not surprising that the analysis of such vital issues as non-intervention, affirmative duties, and humanitarian intervention provides the reader with so little guidance and leaves her with very little that is fresh. "At each step in this inquiry there are difficult issues of domestic political theory. The vertical thesis only serves to formulate them, not to answer them."16 Gertainly! But then, why claim so much for it?

If the only point of this thesis is that "arguments from political theory are relevant to international relations because they both deal with the same issue: the legitimacy of state power," ${ }^{17}$ few will quarrel with Brilmayer. If the point, however, is that because "extremely difficult issues" of diagonal relations are "the analogs for issues that domestic political philosophers do, or should, address," then "as a matter of international law, the problem disappears,"18 one can only dissent: This is a non sequitur. Indeed, it is less arduous to find a rationale for, say, humanitarian intervention, or for limits to the duties of distributive justice across borders, in an international political philosophy that takes into account both the rights of human beings and the special bonds of citizenship in a world of territorial states, than in the tortuous and inconclusive vertical thesis. Domestic political theory is all too able, even when it is not blithely inconsistent, either to justify every kind of coercive act across borders, or to exclude all coercive or all beneficial acts abroad, or to argue for a radical discontinuity between state-citizen and state-noncitizen relations. Thus, it risks providing even less guidance than traditional "horizontal" international theories.

Finally, Brilmayer argues that the vertical limitations of state acts "arise out of political theory, not out of an analogy to personal ethics," whereas "even when contemporary theory does move away from the horizontal paradigm, it does not evaluate state actions in terms of political theory but in terms of personal morality or ethics."19 Ethics, in her view, "deals primarily with an individual's relationship with other individuals, 
a horizontal relationship."20 This is highly questionable: first, because it erects an excessively high barrier between normative political theory and ethics (politics, to be sure, is the realm of coercion, but coercion is quite properly subject to ethical judgment), and second because it distinguishes far too rigidly "states" from "people." States are (certain) people committing certain acts, and ethics deals not only with "horizontal" and personal relations but with hierarchical relations and collective acts as well. Furthermore, if Brilmayer is right, why does she say that her book claims that "international ethics and domestic political justification . . . are not separate areas"?21

20. P. 39.

21. Pp. 1-2. 